\title{
THE ECCLESIOLOGICAL CONTRIBUTIONS OF THOMAS HELWYS'S REFORMATION IN A BAPTIST CONTEXT
}

\author{
MARVIN JONES* \\ Louisiana College
}

\begin{abstract}
The English Separatist movement provided the background for which John Smyth and Thomas Helwys emerged to reconstitute a biblical ecclesiology. Through the study of the New Testament, they came to the position that infant baptism and covenantal theology could not be the foundation for the New Testament church. Both men embraced believer's baptism as the basic foundation in which a recovered church should be built. Unfortunately, Smyth defected to the Mennonites, leaving Thomas Helwys to continue the fledging work known as Baptists. This article will examine the life of Thomas Helwys and his contribution to Baptist ecclesiology; it will also review selected literary works that contributed to the recovery of a New Testament church and the founding of Baptist ecclesiology.
\end{abstract}

KEY WORDS: English Separatism, Puritanism, Baptist, Thomas Helwys, church

\section{Introduction}

Thomas Helwys was the primary leader of the General Baptist Church movement after John Smyth defected to the Mennonites. After investigating into matters of ecclesiology, Smyth sought a true church that had roots back to the apostolic church. Smyth became convinced that there was a true church in existence once he began a dialogue with the Mennonites in Amsterdam. Reviewing Smyth's investigation into the Mennonites doctrine, Walter Burgess states:

As there was a true Church in existence at the time when he arrived at a conviction of the truth, Smyth concluded that he and his company had acted 'disorderly' in assuming baptism for themselves. The right course for them to have taken would have been to seek baptism from those who had already recovered that ordinance. And now that they had found a true church they ought to retrace their

* MARVIN JONES (PhD 2014, Southwestern Baptist Theological Seminary, Fort Worth, Texas; DTheol 2005, University of South Africa) teaches theology at Louisiana College, United States of America. Email: drmdjones@yahoo.com. 
steps, and for the sake of order enter into fellowship with this new found Church and receive the ordinances at the hands of her 'elders' (Burgess 1911: 182).

The decision by Smyth to join the Mennonite church proved to be the breaking point with Helwys. The dispute between Smyth and Helwys resulted in a division between the leadership of the church and the church itself (other members). Most of the church followed Smyth while the remaining members were left under the sole guidance of Helwys. The remaining members became known as 'The General Baptist'.

\section{Methodology}

History has recorded the impact of Helwys on the General Baptist movement yet there remains very little research into the life of the man. This paper will succinctly review the life of Helwys. The historical facts will yield and understanding of the general times and circumstances of his life. His place in history clarifies the meaning of some of the decisions that he made which gives a better understanding of the events.

The paper will include an examination of Helwys's ecclesiological contributions to the General Baptist movement by a select review of his publications. The publications for consideration are The Synopsis of Faith, A Declaration of Faith of the English People Remaining at Amsterdam in Holland, and $A$ Short Declaration of Mystery of Iniquity. The rationale for the selected literature reviews are that they constitute Helwys's earliest written works which reveal his emphasis and progression of thought concerning his Baptist ecclesiology.

Family History

Thomas Helwys was from Nottinghamshire, England. His father was Edmund Helwys of Broxtowe. Edmund Helwys leased Broxtowe Hall, which, according to William R. Estep, was the Helwyses' 'ancestral home' (Estep 1985: 24). Edmund died quite young, leaving his son, Thomas, as executor of the estate. J. Glenwood Clayton states:

Thomas was made executor of the estate, but as he was apparently underage, therefore, the management of the estate was left to two uncles and two friends, Sir Thomas Stanhope and Edward Stanhope. Edmund was a religious man, and his will is prefaced by a confession of faith from which one can infer the religious atmosphere of the home in which Thomas was reared (Clayton 1973: 3).

The childhood of Thomas Helwys was acclimated toward religion. Even so, Helwys was not trained for the clergy but were trained at the Inns of Courts. Thus, Thomas was sent to Gray's Inn, the largest court, so that he could prepare to manage his family's estate. 
During his time at Gray's Inn, the emphasis of Thomas Helwys's education, like his father's, focused upon the studies of common law or general education. W. T. Whitley comments:

The head of such a family deserved the best training possible. Universities were specializing too much in theology. Just adjoining London, on the Westminster dies, were the four Inns of Court, intended chiefly for the profession of law, but also for the education of the sons of the nobility and gentry. The largest and most fashionable was Gray's Inn (Whitley 1934: 241).

It is not certain that Helwys was trained in law as much as general education, but Estep does not rule out the possibility that he, at least, was 'introduced to English law' (Estep 1985: 25). Regardless, he received a substantial education for his day.

After graduation, Thomas returned to Broxtowe Hall and met and married Joan Ashmore, 'possibly of the Ashmore family, seated at Little Eaton, a few miles over the country boundary in Derbyshire' (Burgess 1912: 28). The marriage produced seven children.

\section{Early Puritan and Separatist}

By the year 1600, Helwys had embraced Puritanism. The issue at stake for Helwys was that the Puritans were part of the Church of England and desired to reform the national church. From the Puritans' point of view, the benefits of such reform meant that they could stay in good standing with the crown by adherence to royal supremacy, have the honor of English citizenship, and embrace Protestant theology.

As a Puritan, Helwys became friends with Richard Bernard, who was vicar of Worksop. Joe Early comments on the impact of this relationship. He states:

We do know that Helwys was close friends with the vicar of Worksop and Puritan sympathizer Richard Bernard. Helwys soon began to allow Bernard and other Puritans to hold services in Broxtowe Hall. Although there is no way of knowing who attended these services, the Nottinghamshire region was densely populated with Puritans, so one can imagine that they were well attended. The more Helwys came into league with Puritan sympathies, the more his home became a haven for Puritan teachings (Early 2009: 16).

The atmosphere must have been conducive to move from Puritan to Separatism. The primary difference between Puritanism and Separatism was their respective attitudes toward the Church of England. The former accepted the position that the Church of England could be purified, or reformed, whereas the latter embraced the position that the Church of England was nothing less than an English version of the corrupt Roman Catho- 
lic Church, for example, a false church. Helwys had come to accept the Separatist position. His understanding of Separatism was undergirded by his friendship with John Smyth.

The friendship between Smyth and Helwys was born out of the kindness of Helwys. Per Early, Helwys was instrumental in helping Smyth regain his health. 'Helwys took him to Broxtowe Hall and over several months slowly nursed him back to health' (Early 2009: 17). It is not hard to imagine the conversation between the two men as they contemplated the status of the Church of England, which, consequently, led to the discussion of the differences between Puritanism and Separatism. It must be noted that the above incident took place in 1606, whereas, the first meeting between the two men occurred in 1600 (Early 2009: 16). Thus, their friendship developed over a six year period.

Eventually, the Puritan ideas of Smyth gave way to a Separatist ideology. Helwys supported this move by embracing Separatism. During the year 1606, the church at Gainsborough, near Broxtowe Hall, called Smyth as their pastor. The membership, per Leon McBeth, consisted of 'John Robinson, William Brewster, and William Bradford, some of whom came to America on the Mayflower. Another leader was well-to-do layman, Thomas Helwys' (McBeth 1987: 33).

This congregational church divided into two groups to accommodate their size. The large membership of this congregation meant that it could easily be targeted for persecution. The first group, led by John Robinson, William Bradford, and William Brewster, met at Scrooby Manor House and became known as the Pilgrim Church (Torbet 1950: 34). The second group was led by John Smyth and Thomas Helwys, and it retained the original name of 'The Gainsborough Church' (Torbet 1950: 34).

The Gainsborough Church faced the possibility of persecution. Lawrence Holiday Harris states:

Some of these Separatists were frightened by the memory of the Dissenters Barrowe, Greenwood, and Perry, who were executed in England in 1593. Led by the Gainsborough congregation in 1607, both groups migrated to Protestant Holland (Amsterdam, clarity mine), a tolerant state that welcomed Separatist from about $1595 \ldots$ the other group, from Scrooby Manor Church, led by John Robinson and layman Richard Clyfton, moved to Leyden... (Harris 2001: 4).

The move to Holland is predicated upon persecution. It is hard to imagine that anyone would drastically up-root their lives unless persecution was the source of such a decision. William Estep quotes William Bradford as saying the Separatist were 'molested' and 'resolved to go into the Low Countries' (Bradford 1993: 307). Because of such persecution, in the spring of 1608, the church left England and moved to Amsterdam. 
The church at Amsterdam lived without fear of persecution. McBeth states that 'they had formed their church on the basis of the Old Testament covenant' but had not given much thought to the visible sign of the church or who constituted membership of the church (McBeth 1987: 35). Separatism did not embrace believer's baptism, but it rejected the origin of the Church of England. Therefore, the church at Amsterdam still adhered to the Separatist ecclesiological position. However, it was not to remain in this position long.

\section{Baptist and Baptism}

Smyth, who had rejected the Church of England as being a viable New Testament church, began to question the way in which the Church of England baptized individuals. The logical reasoning was that if the Church of England was not a viable church, then its ordinances could not be valid. This concept was further developed as Smyth continued reading the New Testament. Underwood states:

Examination of the New Testament convinced him that baptism upon profession of repentance towards God and faith in Christ was the New Testament method of admitting to church fellowship, and that the New Testament knew nothing of the baptism of infants. Smyth then drew the logical inference that the baptism which he and his congregation had received in the parish churches of England was worthless (Underwood 1970: 37).

Smyth, after studying the New Testament, concluded that the Baptist position was the most theologically correct. Smyth renounced his baptism by the Church of England and reconstituted the church through believer's baptism. He realized that to functionally baptize the congregation, he first had to baptize himself. Jason Lee comments upon Smyth, writing that 'Smyth shocked his fellow Separatists by rejecting infant baptism and reestablishing his church through believers' baptism. The fact that Smyth had baptized himself added to their bewilderment' (Lee 2003: 71).

Smyth had declared by an act of baptizing himself and his congregation that the church was to be a believer's church, i.e., those that were saved and then baptized in obedience to the Lord's command. Helwys accepted this act of baptism, as he believed John Smyth had led the church to recover a properly constituted church. The result of the act of baptism is that it produced a Baptist church. James Leo Garret comments:

One would hardly dispute the claim, however, that ecclesiology was Smyth's most developed doctrine. He rigorously rejected the baptism of infants, asserted that baptism should only be administered to voluntary or professed believers who are regenerate, retained the baptismal mode of aspersion or affusion, and denied 
that succession in the administration of baptism was necessary (Garrett 2009: 26).

Smyth embraced the principles of New Testament baptism. J. Eric Hankins considers the 'rediscovery of believer's baptism as the final link in completing the Reform which began so inadequately by Henry VIII: the means of actually establishing a pure and visible New Testament church' (Hankins 2002: 17).

Unfortunately, the act of self-baptism did not settle the ecclesiology issue for Smyth. He was not satisfied that the church had been properly reconstituted, and he doubted that his actions were biblically legitimate. Smyth was convicted that it was wrong to baptize himself, especially since he was seeking a New Testament church. His mindset was to find a church that had a linage or succession back to the apostolic church. James Coggins states:

John Smyth and many members of his congregation decided that instead of baptizing themselves they should have asked the Mennonites to baptize them...What they had convinced the Smyth congregation of was that the Mennonites were a true church. According to The Character of the Beast, a true church was one constituted by believer's baptism, and for this the Mennonites certainly qualified (Coggins 1991: 78).

Smyth did not view the Mennonites as a true New Testament church when he first encountered them. He writes that 'seeing there was no church to whome wee could Joyne with a Good conscience to haue baptisme from them, therfor wee might baptize our selues' (Smyth 1915: 757).

Sometime after his self-baptism, Smyth questioned the validity of his own self-administered ordinance. To be clear, he never doubted believer's baptism, but he did examine the church's apostolic succession of the ordinance's administration. Smyth had embraced the concept that a church must have some proof of descending (succession) from the apostles to be a valid church. He disbelieved that he could simply create a church by covenant and then administer the ordinances. Regarding these crucial aspects, Clayton states:

Doubting the validity of his act and feeling the Mennonite Church was a true church administering true ordinances, Smyth decided that he should seek baptism from the Mennonites. Consequently, Smyth and thirty-two members of his part petitioned the Mennonites for membership in their church in February, 1609/10 (Clayton 1973: 6).

At this point in time, Smyth was willing to accept the fact that the Mennonites did have a true constituted church. 


\section{Helwys the Baptist}

Smyth's decision to join the Mennonites led Helwys to separate from Smyth and the rest of the congregation. Helwys and a small group of approximately ten members withdrew from the church and excommunicated Smyth and his followers. Ernest Payne writes:

To his (Helwys-clarity mine) distress he found himself at all three points (Successionism, Hoffmannite Christology, Christians, and the Magistracy-clarity mine), disagreeing with the one whom till then he had so gladly and gratefully followed. Hoffmannite Christology was unorthodox and unsatisfactory. If the baptism which they had reconstituted their fellowship was invalid, what guarantee was there that Mennonite baptism was correct? The whole idea of a necessary human succession was to be rejected (Payne 1962: 7).

To continue as a church, Helwys believed it necessary to defend the ecclesiology that he had embraced. He immediately began to write $A$ Declaration of Faith of English People Remaining at Amsterdam in Holland. McBeth considers this book confirmation that 'the Helwys group continued to adhere to the Baptist principles earlier announced and then abandoned by Smyth' (McBeth 1987: 38).

For two years, Helwys pastored the congregation in Amsterdam but did not consider this a permanent solution. His work, A Short Declaration of the Mystery of Iniquity, is a call for religious liberty of conscience and the responsibility of propagation of the gospel through the church. W. T. Whitley comments on the impact of the book as he states:

He seems to deserve the sole credit for discerning and practicing that a Christian church must bear witness to the truth, nay, that this is its primary duty, for the sake of which it is created. It is the one point wherein he advances upon Smyth and completed the Baptist position... this little volume closes with the invitation to "come and lay down their lives in their own country, for Christ and His truth' (Whitley 1923: 34).

Helwys took the church back to Spitalfield, England and planted the very first English Baptist Church on English soil, thus, starting the General Baptist movement within England.

\section{Helwys's Selected Literature Review}

\section{Synopsis of the Faith of the True English Church}

The Synopsis of Faith which was originally written in Latin, contains nineteen articles that discuss a statement of faith. The occasion of this statement is Helwys's and Smyth's dispute concerning the dissolution of the English Baptist Church for the purpose of joining the Mennonite Church. Helwys 
sent a letter to the Waterlander Mennonites, warning them to be cautious of accepting Smyth into their congregation. Early confirms this as he writes:

Helwys told the Waterlanders that Smyth and his followers had been 'justly excluded' and were impenitent in their sin... The tone of the letter is congenial. He was not castigating the Waterlanders for considering Smyth, but rather attempting to explain what Helwys and his followers had done to Smyth and his adherents. Along with this letter he sent them his Synopsis of Faith, a nineteen article Latin confession of faith (Early 2009: 26).

Early compares Helwys's Synopsis of Faith with Smyth's A Short Confession of Faith. Smyth wrote twenty articles, as compared to Helwys's nineteen articles. Early states that fifteen articles in Helwys's Synopsis are 'almost identical' to Smyth's Confession of Faith (Early 2009: 26). Yet, regardless of such vast similarities, Helwys noted the difference between his followers' theological convictions and Smyth's.

In article 6 of Helwys's Synopsis of Faith, the Christological emphasis is directed to the Mennonite Christology. Article 6 reads:

That Jesus Christ in the fullness of time, was made known, in the flesh, was made from a woman, conceived and born from her, the Holy Spirit overshadowing her, the fruit of the womb, the seed of Abraham, Isaac, Jacob, and David according to the flesh. And thus a true man, he was circumcised, baptized, he prayed, was tested, was afraid, having no experience of the judgment of the age, he was hungry, thirsty, weary, ate, drank, slept, grew in stature and knowledge, was crucified, died, was buried, resurrected, ascended into Heaven, with all power in Heaven and earth having been delivered to him, being the only King, Priest, and Prophet of his church. And (he is) one person, true God and true man (Rich 2009: 238-238).

This article pointedly states that Jesus had a human body, indicating that Helwys accepted the traditional Christological formula. Helwys understood the differences with the Mennonites in Christology to be a strong point of contention for the two congregations. Thus, his comment upon Christology demonstrates the lack of theological core values of the two congregations.

The second major difference between Smyth and Helwys is found in Article 9. Helwys established his ecclesiology by differentiating Baptist ecclesiology with Mennonite ecclesiology. Article 9 reads:

That the Church is the assembly of faithful people, baptized into the name of the Father, Son and Spirit, by which at the appointed time they confess their faith and sins: having the power of Christ, to preach the word, to administer baptism and the Lord's Supper: to elect their ministers, and to expel: both to accept and expel their members according to the statutes of Christ (Rich 2009: 239). 
This article, coupled with article 10 and article 11, demonstrates Helwys's conviction that a church must only be constituted of believers who have the responsibility of mutual accountability at the Lord's Supper. Even though his conclusion was in accord with the Mennonites, Helwys's emphasis made the case that his Baptist Church was a true church that did not need the validity of Smyth's idea of 'successionism', or the approval of the Mennonites via successionism.

There is no doubt that the Synopsis of Faith was written in a heated debate with Smyth. However, regardless of the circumstances, the Synopsis of Faith served to lay the ground work for the ecclesiastical Baptist tradition. This work emerges as an elementary introduction to Helwys's ecclesiological thought.

\section{A Declaration of Faith of the English People Remaining at Amsterdam in Holland}

A Declaration of Faith of the English People Remaining at Amsterdam in Holland has the notoriety of being the very first Baptist Confession of Faith (Burgess 1911: 212). The date for this confession is 1611 . The time frame reveals a critical issue that is often overlooked. The Synopsis of Faith was written either in the summer or fall of 1610 or possibly in the early winter of 1611 , just after Smyth petitioned the Mennonites for membership. Smyth, of course, wrote his Short Confession as a clarification and presentation of his church's faith so that he could start negotiations with the Mennonites. Thus, Coggins dates Smyth's Short Confession between 'May and early July of 1610' (Coggins 1991: 88). This date indicates that the Synopsis, which was in response to Smyth's petition to the Mennonites, was possibly a shorter version of Helwys's Declaration of Faith. If that hypothesis is correct, that would allow Helwys time to develop his ecclesiology, which undergoes modification from the Synopsis to its final form in the Declaration.

This confession lists twenty-seven articles that are designed to show the differences between the Mennonite church and the faith of the English people at Amsterdam. William Lumpkin writes:

Obviously, it owed much to John Smyth, though it goes beyond his confessions at a number of points: in urging the independence and autonomy of the local church, in denying a succession in church life, and in rejecting the Mennonite prohibitions against oaths, the bearing of arms, participation in government, and having dealings with excommunicants. It aimed, indeed, to distinguish its authors from the Mennonites (Lumpkin 1989: 115).

Helwys's theological maturity grew as he expanded his arguments for theology and ecclesiology. Early states: 
Helwys repudiated every tenet of Waterlander theology that Smyth now maintained and that had been included in his Synopsis. He now affirmed original sin, the magistrate's ability to be a member of the church, and oath taking. He denied free will and Hoffmannite Christology. Helwys's soteriology was now a mix of Calvinism and Arminianism. In matters of original sin and the will, he became more Calvinistic than Arminian. Yet in matters of atonement and the perseverance of the saints, Helwys remained strictly Arminian (Early 2009: 35).

The fundamental distinction of Baptist ecclesiology is maintained in that Helwys kept Smyth's position that believer's baptism constitutes the church. Article 13 states:

That every Church is to receive in all their members by Baptism upon the Confession of their faith and sins wrought by the preaching of the gospel, according to the primitive instruction. Matthew 28: 19. And practice Acts 2: 41. And therefore Churches constituted after any other manner, or of any other persons are not according to Christ's testament (Lumpkin 1989: 120).

The impact of this article is not to be understated. In Helwys's mind, the congregation at Amsterdam became Baptist by (1) rejecting the Separatist view of a covenanted church, and placing the emphasis on regeneration for membership evidenced by public baptism, and (2) rejecting Smyth's concept of the Mennonite church successionism (McBeth 1987: 38). In fact, Helwys continued to embrace the theological relationship of baptism to the gospel as foundational for the church's membership.

The focus upon the New Testament ecclesiology allowed Helwys to reject any need to embrace church successionism for viability. Whether intentionally or unintentionally, Helwys rejected the infant baptism of the Separatist movement as a viable rationale for membership, and, at the same time, rejected the need for Mennonite successionism.

Helwys continues to ferret out Baptist ecclesiology in Article 24. It reads:

That Magistracy is a Holy ordinance of God, that every soul ought to be subject to it for fear only, but for conscience sake. Magistrates are the ministers of God for our wealth, they bear the sword for nought. They are ministers of God to take vengeance on them that do evil, Romans 13. That it is fearful sin to speak evil of them that are in dignity, and to despise Government. 2 Peter 2: 10. That we are to pray for them, for God would have them saved and come to the knowledge of his truth. 1 Timothy 2: 1-4. And therefore, they may be members of the Church of Christ retaining their Magistracy, for no Holy Ordinance of God debars any from being a member of Christ's Church (Lumpkin 1989: 122).

One may conclude that Helwys directed Article 24 towards the Mennonites who rejected civil servants as church members. However, the consequence 
of this statement is that church membership in a Baptist church was open to all believers without regard to vocation or civil community standing. Basically, this article impacted the existing social structure of the church. Membership in a Baptist church was defined by one's standing before God and not one's status in the community. The focus upon one's salvation places church membership as a means of the inner work of the Holy Spirit upon the human heart. In other words, the Holy Spirit creates church members by means of salvation and not covenant obligation.

One other article warrants mention, as it pertains to Baptist ecclesiology. Helwys indicated that each church is local and visible. He affirms this position by stating the officers of the church are directly related to the congregation. Article 22 reads:

That the officers of every Church of congregation are tied to by Office only to that particular congregation whereof they are chosen, Acts 14: 23 and 20: 17. Titus 1: 5 . And therefore to be vested with all reverence, as to continuing the Holy Word of God, which only is our direction in all things whatsoever (Lumpkin 1989: 123).

It is well noted that the emphasis on this article is placed upon the officers of the congregation. Yet, the officers of the church could not meet the requirements unless there was a local congregation to which they serve. This is tantamount to placing the emphasis of the ministry at and for the local church body as an Independent church, i.e. free from all ecclesiastical control.

Free from the constraints of any alleged ecclesiastical authority that would impose leadership upon a local congregation, the church had the responsibility of electing its own leadership. Thus, by rejecting infant baptism, embracing local church responsibility for leadership, and insisting that believer's baptism is the only means of church membership, Helwys moved 'toward a free-church model that involved a Spirit-led return to Scripture from the historical errors of the papacy, culminating in the biblical churches that became known as Baptist' (Yarnell 2007: 153). In effect, Helwys had declared Baptist ecclesiology!

\section{A Short Declaration of the Mystery of Iniquity}

A Short Declaration of Mystery of Iniquity may be entitled after Paul's phrase in 2 Thessalonians 2: 7, which states that 'the mystery of iniquity is already at work' (2 Thessalonians 2: 7). Helwys picked up on the theme of iniquity at work and applied it to the lack of religious liberty within England. He wrote the book to inspire the English church to return to England and perhaps face severe persecution. Joe Early Jr. claims that the book was written in Holland and published there in late 1611, prior to his return to English soil 
(Early 2009: 36). If Early is correct, then it is safe to assume that the book was also written to the church for the purpose of preparing them for persecution from their fellow Englishmen. Regardless of the actual recipients, the book was born out of a sense of obligation to return to England and initiate change. Clayton confirms this, as he states that Helwys "became progressively convinced that he had acted improperly in fleeing England to avoid persecution' (Clayton 1973: 7).

The Mystery of Iniquity is the catalyst for religious liberty. Robert Torbet makes the statement that this book is 'the first claim for freedom of worship to be published in the English language' (Torbet 1950: 38). This book is apocalyptic in nature, which may stem from Helwys's father's work, which is entitled $A$ Marvel Deciphered. Burgess describes this work as:

A topical patriotic tract called forth by Protestant feeling engendered by the Spanish attack on England. The writer makes a veiled allusion to Queen Elizabeth as foreshadowed by the woman clothed with the Sun in the 12th chapter of Revelation and to the Pope as the Dragon that made war on her (Burgess 1912: 110).

The apocalyptic style of writing was utilized by both father and son when addressing a topic that was dangerous for the individual author.

Another facet that must be taken into consideration regarding England is the religious climate of that time. Estep points out that the English were open to the gospel message, as evidenced by the five congregations that were in existence in 1626, which include the original Helwys church (Estep 1993: 316). The evangelistic zeal of Helwys cannot be denied, as he wrote both positively and negatively about the issue of returning to England. From the negative approach, Helwys, in the appendix, criticizes the Separatists for remaining in Holland. William Estep writes:

But these men flee to cities to which they cannot preach the Gospel, being of a strange tongue, neither have they any intent nor meaning to preach to those cities. Their fleeing is not to that end, but to save themselves, for being as 'sheep in the midst of wolves' and for being delivered up to councils, and for being brought to governors and kings, for Christ's sake, in witness to them and to the Gentiles (Helwys 1998: 149).

Helwys desired to teach the church to advance the gospel through evangelism. Helwys states 'the disciples of Christ cannot glorify God and advance his truth better than by suffering all manner of persecution for it, and by witnessing it against the man of sin, with the blood of their testimony' (Helwys 1998: 150).

The ministry of the church had a practical effect upon Helwys as he desired to lead the church to proclaim the gospel in England. He is convinced 
that the Baptists had restored the true New Testament church. Subsequently, he wanted to evangelize England within his ecclesiological and theological framework. Thus, he writes 'so we wish all to do fear God and seek the glory of his name, and come and lay down their lives in their own country for Christ and his truth' (Helwys 1998: 154).

With the above as the background, the Mystery of Iniquity evidences that Helwys developed the biblical ecclesiology of the Baptist church. He structured the book in four parts. The first part (Book One) deals with the first beast, or the Church of Rome. Helwys states:

'And it was given unto him (speaking of the beast that had seven heads and ten horns) to make war with the saints and to overcome them. And power was given him over every kindred and tongue and nation.' Who can deny but this is general, eve a general desolation when the saints are overcome, 'and when all that dwell, upon the earth (as follows verse 8) shall worship the best'. All our particular knowledge of the fulfilling of this prophecy will make it more evident. And who does not know and see that this prophecy is fulfilled in that Romish mystery of iniquity, "who yet sits upon many waters, with whom have committed fornication the kings of the earth, and the inhabitants of the earth are drunken with the wine of her fornication?' Revelation 17: 2 (Helwys 1998: 12).

Helwys rationalized that Roman Catholicism was the mother of all abominations (infant baptism, popes, lack of tolerance to dissenters, etc) so that if the mother gave birth, then the child must have been a beast.

With the groundwork laid, Helwys continued to examine the second beast. He states:

Which way now (in finding out the second beast) shall we be able to look beside that great hierarchy of archbishops and lord bishops? Are not you they that pretend (in meekness and humility) the word and power of the Lamb, who says, 'Learn of me that I am meek and lowly, etc.', but exercise the power of the beast, speak like the dragon? Have you not made and set up the image of the beast? Is not your pomp and power like his? And has there not been much like cruelty used by that power? Does not the blood of the dead cry? Are not your canon and consistories, and all the power that belongs to them, with all the rest of your courts, offices, and officers, are not these part of the image? Are they not like the beast? (Helwys 1998: 16).

Helwys demonstrated that Rome (the first beast) and the Church of England (the second beast) have nothing in common with true Christianity.

Book Two is his defense of freedom of conscience. Helwys defended freedom of conscience of the Baptist church, knowing that he and the church could be accused and probably condemned as heretics by the Church of England. As a consequence, they could have been held liable as 
civil traitors to the nation of England and possibly could have received the death penalty. Yet, regardless of the precarious position, he addressed this section to the king. The basis of this section is that Helwys recognized the right of the King to govern England. He states:

Our lord the king has power to take our sons and daughters to do all his services of war and of peace, year, all his servile (civil) services whatsoever. And he has power to take our lands and goods of whatsoever sort or kind, or the tenth thereof to use at his will... in all these things our lord the king is to be submitted unto and obeyed... Thus does God give our lord the king power to demand and take what he will of his subjects, and it is to be yielded to him, and to command what ordinance of man he will, and we are to obey it (Helwys 1998: 33).

Helwys does not deny the rights of the king to govern the English subjects. In all matters that pertain to civil life, Helwys defended the king's right to govern. The problem is that Helwys understood that the throne was limited to civil matters only. Thus, the king and government did not have the right to govern the church or force religious service upon the subjects.

Book Three rebukes the Puritans who never severed their relationship with the Church of England. Basically, Helwys understood that the Puritans were part of the second beast. Since the Puritans were part of the Church of England, they were deemed 'false prophets' (Helwys 1998: 149). Helwys's criticism of the Puritans allowed him to defend Baptist ecclesiology against that of Puritan Presbyterianism. Helwys acknowledged that Christ, not the King of England, the Archbishop, or lords, was / is the head of the church (Helwys 1998: 77-80).

Book Four deals with the Separatists and, particularly, Helwys's former friend, John Robinson. Helwys charged Robinson and the Separatists with inconsistency in their theological position. Even though the Separatists desired to separate from the Church of England, they still retained their baptism from the national church. Helwys could have accurately accused the Separatists of not actually separating from the Church of England.

The Separatists' allegiance to the Church of England provided Helwys the opportunity to discuss the importance of baptism within the framework of ecclesiology. He examined the Church of England's covenantal approach to the Scriptures and found it lacking in substance. He argues, 'And whereas he says he will make a new covenant not according to the old, you will say and have it according to the old.' (Helwys 1998: 122). Covenantal theology declared that there was/is an existing correspondence between the Old Covenant and the New Covenant. The continuity of the testaments allowed Israel to be interpreted as the Church throughout both the Old Testament and the New Testament with emphasis on infant baptism as a corollary sign of Old Testament circumcision. 
The issue for Helwys was the significance of baptism in relationship to ecclesiology. He condemned the Separatists for not being consistently biblical in the founding of their independent churches. Helwys acknowledged the covenant foundation of Separatist churches when he writes: 'And now to become Christ's you say you are called and separated from the world by the Word of God, and joined together by voluntary profession of the faith of Christ in the fellowship of the gospel. This is your confession, wherein you have erred, as may plainly appear' (Helwys 1998: 92).

The error that Helwys spoke of concerned the relationship between baptism, the covenant, and church membership. He denounced the concept of a gathered community without the sign of entering that community, which was believer's baptism.

And to show you that you are not joined to Christ, you being of the world before you constituted or set up your church by your own confessions, the Word of the Lord does evidently declare that there is no way for them that are of the world, who are not in Christ, but enemies to Christ, as all that are of the world are, there is no way to join and come to Christ, but only to 'amend their lives and be baptized' Acts 2: 38 (Helwys 1998: 92).

Helwys noticed that a true church gave the testimony of baptism, which is the testimony of salvation. Therefore, a gathered community established by covenant was not the complete picture of a New Testament Church. However, a gathered community established by faith in Christ and evidenced with baptism was a sign of a true New Testament Church.

To conclude this review of $A$ Short Declaration of the Mystery of Iniquity, it must be noted that the tract was a call for religious liberty for all dissenting groups that even Helwys disagrees with at key points. Yet the book declares that even though there should be religious liberty, there is a more definite consideration: the Puritans, the Church of England, and the Separatists all miss the meaning of ecclesiology. This leaves the reader with the impression that Helwys and the Baptist church understood the New Testament teachings on the church. The underlying tone is that Baptists are not of the beast, i.e., the Baptist church is the true church.

\section{Conclusion}

Thomas Helwys has often been overlooked in the annals of history. Yet, his contributions to Baptist ecclesiology have been valuable to the movement itself. For that matter, he stands in the category of an apologist theologian for the Baptist cause. Historians acknowledge his work, A Short Declaration of the Mystery of Iniquity, for being the first book to call for religious liberty, but the book presents an unashamed Baptist ecclesiology when most, if not all, 
other attempts at English reform retained concepts of covenant theology (infant baptism) and / or state-church connectionalism.

It must be noted that Helwys's conviction to return to England to plant the first Baptist church on English soil was out of the biblical conviction that the church must evangelize those who could hear the gospel without hindrance of language. The church at Holland, even though formulated there, could not perpetuate the gospel simply because of the language barrier. Helwys decided that the primary focus of ecclesiology is the gospel itself, which is a watershed mark of Baptist ecclesiology. He must be given credit for the theological conviction and conclusions to which he contributed in this area. To sum up his life and work in a succinct statement, Helwys was a pioneer of Baptist ecclesiology and religious liberty.

\section{Bibliography}

Estep WR (1993) Anabaptist, Baptist, and The Free Church Movement. Criswell Theological Review 6(*): 303-307.

Burgess WH (1912) The Helwys Family. Baptist Historical Society Transactions $3(*): 18-30$.

Burgess WH (1911) John Smyth, The Se-Baptist, Thomas Helwys and the First Baptist Church in England. London: James Clark \& Co.

Clayton JG (1973) Thomas Helwys: A Baptist Founding Father. Baptist History and Heritage 8(1): 2-15.

Coggins JR (1991) John Smyth's Congregation. Scottdale, PA: Hearld Press.

Early J (2009) The Life and Writings of Thomas Helwys. Macon, GA: Mercer.

Estep WR (1993) Anabaptist, Baptist, and The Free Church Movement. Criswell Theological Review 6(*): 307-317.

Estep WR (1985) Thomas Helwys: Bold Architect of Baptist Policy on Church-State Relations. Baptist History and Heritage 20(3): 24-34.

Garrett JL (2009) Baptist Theology: A Four Century Study. Macon, GA: Mercer University Press.

Hankins JE (2002) Reformed Sacramental Theology as a Key to Understanding John Smyth's Affirmation of Believers' Baptism. PhD Thesis, Southwestern Baptist Theological Seminary, Fort Worth, Texas.

Harris LH (2001) The Origins and Growth of Baptist Faith. Spartanburg, SC: The Reprint Company.

Helwys T (1998) A Short Declaration of the Mystery of Iniquity, ed, Richard Groves, Macon, GA: Mercer University Press.

Helwys T (1610) A Declaration of Faith of the English People Remaining at Amsterdam. In Lumpkin WL (ed) Baptist Confessions of Faith. Valley Forge, PA: Judson, 114-123. 
Lee J (2003) The Theology of John Smyth. Macon, GA: Mercer University Press.

Lumpkin WL (1989) Baptist Confessions of Faith. Valley Forge, PA: Judson Press.

McBeth LH (1987) The Baptist Heritage. Nashville, TN: Broadman Press.

Payne EA (1962) Thomas Helwys and The First Baptist Church in England. London: Baptist Union of Great Britain and Ireland.

Rich AD (2009) Thomas Helwys First Confession of Faith, 1610. The Baptist Quarterly 43(4): 235-241.

Smyth J (1915) The Works of John Smyth, Fellow of Christ's College, 1594-1598. London: Cambridge University.

Torbet RG (1950) A History of the Baptist. Valley Forge, PA: The Judson Press.

Underwood AC (1970) A History of the English Baptists. London: Baptist Union of Great Britain and Ireland.

Whitley WT (1923) A History of British Baptist. London: Charles Griffin and Company.

Whitley WT (1934) Thomas Helwys of Gray's Inn and Broxtowe Hall, Nottingham. Baptist Quarterly 7(*): 241-255.

Yarnell MB III (2007) The Formation of Christian Doctrine. Nashville, TN: B\&H Publishing Group. 